\title{
GUIDELINES FOR ENHANCING CLINICAL SUPERVISION
}

\section{Dr Marthie C Bezuidenhout}

B Cur (I et A), M Cur and D Litt et Phil

Senior lecturer, Department of Health Studies, University of South Africa

Corresponding author: bezuimc@unisa.ac.za

Keywords: Clinical supervision; reflective thinking and learning; support; guidance

\begin{abstract}
Clinical supervision is widely recognised as important and constructive in nursing and other health professions, but how is it actually done? All nurses, regardless of education, experience, or area of work, are encouraged to engage in the process of supervision, yet there is little practical guidance available as to how it should be done. The aim of this article is to firstly ascertain what professional nurses understood under the term 'clinical supervision' and secondly to provide guidelines for improving the process of supervision. Reflection helps one to understand the impact of one's actions and improve one's professional skills. It is therefore important for nurses and managers to develop a reflective approach to their work in order to make contextually appropriate changes when they are required in their professional practice. A qualitative, exploratory and descriptive research design was utilised where results from narrative sketches and literature control served as the basis for deducting and describing guidelines for enhancing reflection during the process of supervision. The conclusions drawn from the related findings are that the respondents know what clinical supervision encompasses but did not indicate the necessity of applying reflective learning during the process of clinical supervision.
\end{abstract}

\section{OPSOMMING}

Kliniese toesighouding word as belangrik en konstruktief beskou in verpleging en ander gesondheidsberoepe, maar hoe word dit in werklikheid gedoen? Alle verpleegkundiges, ongeag hulle opleiding en ervaring of plek van werk, word aangemoedig om betrokke te raak by toesighouding en tog is daar min riglyne beskikbaar van hoe dit uitgevoer behoort te word. Die doelstelling van hierdie artikel is om eerstens aan te dui wat verpleegkundiges onder die term 'kliniese toesighouding' verstaan, en tweedens om riglyne daar te stel vir die verbetering van die toesighoudingsproses. Refleksie help persone om die impak van hulle aksies te begryp ten einde hulle professionele vaardighede te verbeter. Dit is dus belangrik vir verpleegkundiges en bestuurders om ' $n$ reflektiewe benadering tot hulle werk te ontwikkel ten einde toepaslike kontekstuele besluite te kan neem waar dit nodig mag wees in hulle professionele praktyke. ' $n$ Kwalitatiewe, verkennende en beskrywende ontwerp is gebruik waartydens bevindinge, gebaseer op narratiewe sketse en 'n literatuurstudie, as basis dien vir die maak van afleidings en die voorsiening van riglyne vir die bevordering van die toesighoudingsproses. Die gevolgtrekkings toon aan dat die respondente weet wat toesighouding behels, maar dat hulle nie die noodsaaklikheid om reflektiewe leer toe te pas tydens die proses van kliniese toesighouding aangedui het nie. 


\section{INTRODUCTION}

Media headlines such as: "Verskriklik om jou ma só in tehuis te sien" ("It's terrible to see your mother in such a state in an old age home") which suggests personnel induced bruises and lacerations (Van Wyk, 2001:10) and "Lyk dalk opgegrawe na voorval in hospitaal" ("A corpse dug up after an incident in hospital") where the latter refers to a patient being hit over the head with a bedpan (Meyer, 2001:10), are very disturbing. How can accusations like these be associated with professional service rendering? Where does supervision come in to ensure a measure of safety, if not quality, in patient care?

Clinical supervision is supposed to be one of the central activities in the profession of caring and can also be seen as a tool for quality assurance (Severinsson \& Hallberg, 1996:151). All nurses, regardless of education, experience, or area of work, are encouraged to engage in the process of supervision, yet there is little practical guidance available as to what the process encompasses and how it should be done. The aim of this research was to ascertain what professional nurses understood under the concept 'clinical supervision' and to provide practical guidelines for enhancing clinical supervision.

\section{BACKGROUND AND PROBLEM STATE- MENT}

Clinical supervision refers to the professional entering into a relationship with the practical situation, and having the confidence to enter into an equal partnership with other health care professionals in their quest to make a real contribution to health and health care.

Supervisors usually move up from the ranks of functional workers and are not all equipped for the management function, nor are they always accepted in that position (Nash, 1990:72). As professionals become more senior they are required to become supervisors in their first level management role, often without orientation or guidelines as to what supervision encompasses. Supervision is often associated negatively with disciplinary dealings between managers and their staff. These dealings are seen as punitive and can carry impressions born out of previous negotiations between superiors and subordinates (Butterworth \& Faugier, 1998:9).

Of special concern is the implementation of supervision in nursing organisations and its role in promoting quality nursing care. In the practice of clinical supervision, the emphasis is often heavily on the problems of nursing practice, as a result, any creative, new ideas on the part of the supervised employee are easily ignored (Paunonen, 1991:229), thus not tending to growth opportunities. Supervisors have a wide range of concerns that structure their daily work. While many tasks are mundane, a greater number are of major significance in defining quality in programming or effective practice, therefore reflection is necessary to make the best choice when having to reason out the most appropriate alternative to any decision.

Complaints about poor patient care, neglect and even patient abuse in public hospitals are frequently reported in the media. How come these incidents happen if effective supervision is in place in health care services? Are health service unit supervisors aware of their role, do they know what it entails and can they apply their clinical supervisory function effectively? Clinical supervisors should be alert to assessing the clinical risk that members of staff may present to their patients.

The underlying assumption was that clinical supervisors, who are attentive to what goes on in the supervisory session, will be aware of staff who are ignorant of the consequences of incompetent practice, and can therefore take remedial action.

\section{LITERATURE REVIEW}

It is necessary to briefly explore the meaning and content of clinical supervision and reflective learning before continuing.

\section{Clinical supervision}

Many different definitions exist for supervision; some focusing on the how while others emphasise the what of supervision. Several definitions are aimed at acknowledging clinical supervision as a key element in enabling registered nurses to maintain clinical com- 
petence and to be more personally responsible for their own practice.

Clinical supervision is a term used to describe a formal process of professional support and learning which enables individual practitioners to develop knowledge and competence, assume responsibility for their own practice and enhance consumer protection and safety of care in complex situations (Department of Health [UK], 1998). Bishop (1998:8) defines clinical supervision as a designated interaction between two or more practitioners, within a safe and supportive environment, which enables a continuum of reflective, critical analysis of care, to ensure quality patient services.

In reviewing the definitions of different authors the following key phrases are relevant to clinical supervision:

a formal process of professional support and learning

assuming responsibility for practice enabling practitioners to share and learn from experience enhancing consumer protection and safety of care

- $\quad$ a formal arrangement enabling nurses to discuss their work

- $\quad$ regularly learning from experience and improving competence

- $\quad$ sustaining and developing professional practice

- $\quad$ the development of professional skills

- $\quad$ reflective practice

- $\quad$ quality patient services

- $\quad$ a designated time for interaction between practitioners (Driscoll 2000:8).

\section{A cyclical model for supervision}

The Cyclical Model (Page \& Wosket in Van Ooijen, 2000:10-13) forms a comprehensive framework for the whole of supervision. It provides a step-by-step guide as to what to do, starting from the first meeting between potential supervisor and supervisee. Figure 1 represents a diagram of a supervisory session in five stages.
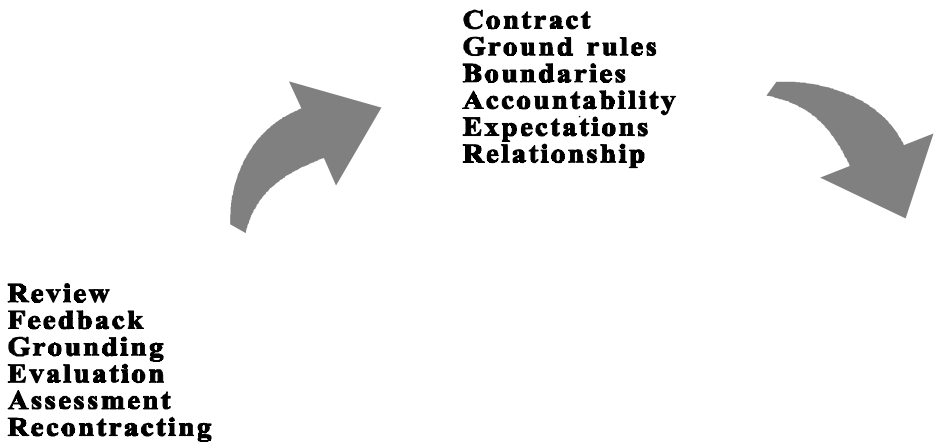

Focus

Issues

Objectives

Presentation

Approach

Assessment

Priorities
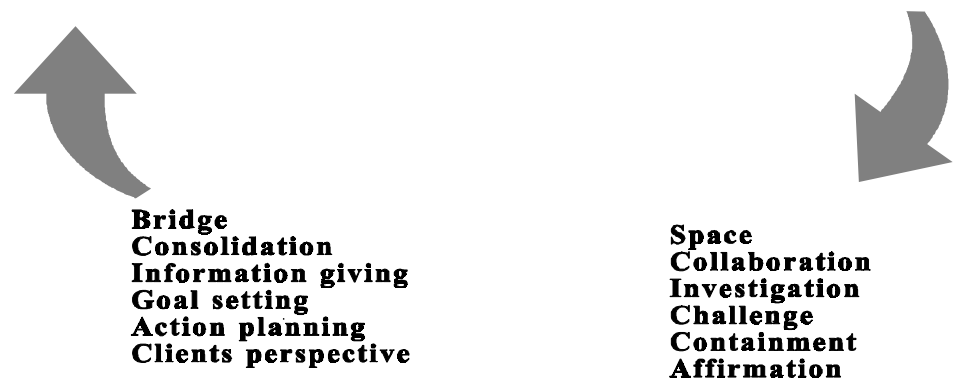

Space

Collaboration

Investigation

Challenge

Containment

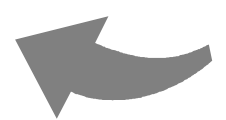

Affirmation

Figure 1: Cyclical Model for supervision (Page \& Wosket in Van Ooijen 2000:11) 


\section{Stage 1: Contract}

Before two or more people decide to start a supervisory relationship, they will need to discuss a contract, so that those concerned will know how they are expected to function. Between them they will set the ground rules and boundaries, decide who is accountable for what, and discuss any expectations that both have of the process and what type of relationship is preferred.

\section{Stage 2: Focus}

It is important that the topic/area/issue for discussion be agreed upon. Having agreed on the focus, it is necessary to reflect upon it satisfactorily and plan possible action, therefore objectives need to be clarified, and the presentation method, approach and priorities be determined.

\section{Stage 3: Space}

The space stage is characterised by a tolerance of confusion and not knowing, and commitment to exploration, which may at times be quite challenging for the supervisee. The relationship between the supervisor and supervisee needs therefore to be collaborative and supportive with the nature of reflective alliance. Reflection provides space for both the supervisee and supervisor to reflect on the issue brought before them as well as on the supervisory process itself.

\section{Stage 4: Bridge}

Having reflected thoroughly on an issue, the clearer perspective is consolidated by, for example, the supervisor asking, "how do you see things now?" maybe followed by "what do you want to do with it?" It is at this stage that the supervisor may give relevant information or experience if it seems useful. Having consolidated the reflection and discussed relevant information, the supervisee may then set goals and plan action, while considering what effect such action will have on others concerned such as the client.

\section{Stage 5: Review}

It is useful to set aside time at the end of each supervisory session to evaluate the session itself, in order to see what worked, what did not, and how useful the session was overall. In addition, it is good practice to build into the contract, regular reviews of the whole process.

\section{The role of reflection in the supervisory process}

Reflection means throwing back an image, thoughts and memories, in cognitive acts such as thinking, contemplation, meditation and other forms of attentive consideration, in order to make sense of, and to make contextually appropriate changes if they are required (Burns \& Bulman, 2000:3; Taylor, 2000:3).

Clinical supervision is something which affects all practising nurses, as it facilitates nurses' reflections on difficulties in caring, and equips them with strategies for how to act in the nurse-patient relationship (Severinsson \& Hallberg, 1996:152). The focus of supervision needs to be the nurse-patient interaction, but it also involves interactions between the nurse and other members of the health care team, as ultimately, these will have an effect on the patients. Through reflection that takes place in supervision, nurses are able to look at their practice in a different way, helping them to improve their outcomes (Van Ooijen, 2000:5). When using a reflective approach to supervision, practice can be enhanced through a process of regular clinical feedback, learning and support. The ability to think in a systematic and rational way separates humans from other species and gives people reflective consciousness. Thinking is thus integral to reflection.

Reflection helps people understand the impact of their actions and improve their professional skills. Reflection, both in, and on action, can be seen as a legitimate tool for increasing one's capacity for experience in clinical leadership. It is therefore important for nurses and managers to develop a reflective approach to their work in order to sustain reflective practice through their professional lives, and by so doing, always strive for improvement in service rendering.

According to several authors in Van Aswegen, Brink and Steyn (2000:124) reflective learning is the process of making a new or revised interpretation of the meaning of an experience, which guides subsequent understanding, appreciation and action. It involves critical analysis and the interpretation of an experience, openness to new information, acceptance of self-reality, a change in personal meaning structure, resolu- 
tion, review of past values in relation to the changed perspective, and the examination of implications for future behaviour and others.

The difference between routinely thinking and reflective thinking is that the former is relatively static and largely unresponsive to changing situations, while the latter involves a willingness to learn and change by purposefully going through the events, often some time after they have occurred. Conway (1994, in Driscoll, 2000:20-21) describes reflection as “... a process of looking back on what has been done and pondering on it and learning lessons from what did or did not work ... the act of deliberation, when the practitioner consciously stops to think, what shall I do now?" Taylor (1994:237) shows that, when nurses critically reflect on ordinary and everyday practice events in nursing those same practitioners can become extraordinary effective in contributing to patient outcomes.

The process of reflection and the process of clinical supervision intersect at the point of wanting to intentionally learn something based on personal experience. In clinical supervision, it is the intention of the supervisee to learn something by sharing their experience of clinical practice with the clinical supervisor. Clinical supervision is thus the mechanism by which safe, guided reflective practice can occur (Driscoll, 2000:21).

Numerous mechanisms in clinical practice offer an opportunity for reflection such as handover times, teaching sessions, case conference, staff meetings, attendance of doctor's rounds, letters of complaint and others. However, many of these opportunities may not be focused on reflecting about clinical practice, while there may be an intention to learn, there is little followup on what actions arose from spending the time on reflecting on practice. According to Driscoll (2000:22) talking, listening and reading can be helpful mediums for reflection, but are more powerful if shared with others rather than keeping things to yourself.

According to Bandman and Bandman (1995:77) critical thinking, which is required in the supervising process, is "... the rational examination of ideas, inferences, assumptions, principles, arguments, conclusions, issues, statements, beliefs and actions".
It can therefore be said that critical thinking encompasses scientific reasoning, the use of the nursing process, decision-making and reasoning about issues. It is required to make contextually appropriate changes where they are required.

What is the relationship between critical thinking and reflective practice? Brookfield's (1987:36) key components of critical thinking namely, identifying and challenging assumptions and imagining and exploring alternative ways of thinking and acting, are key activities undertaken during the analysis phase of a reflective process (Burns \& Bulman, 2000:30), and are paramount to effective supervision.

\section{PURPOSE AND OBJECTIVES OF THE RESEARCH}

The purpose of this study was to explore and analyse the views of professional nurses with regard to the meaning of the concept 'clinical supervision', so that shortcomings in their supervisory role could be identified. Hence the objectives were to firstly, ascertain what they understood under the term clinical supervision and secondly, to provide guidelines for improving the process of supervision.

\section{ASSUMPTIONS ABOUT CLINICAL SUPERVISION}

The assumptions formulated by Butterworth (1998:13) are applicable:

- $\quad$ Competence should be constantly redefined and improved throughout professional life.

- $\quad$ Critical debate about practice activities is a means to professional development.

- $\quad$ Clinical supervision serves as protection for independent and accountable practitioners.

- $\quad$ The process of clinical supervision should begin during training and education, and continue thereafter as an integral part of professional development.

- $\quad$ Clinical supervision requires time and energy and is not an incidental event.

\section{RESEARCH STRATEGY AND METHOD}

A qualitative, exploratory and descriptive design was utilised to conduct research (Mouton \& Marais, 1992:45; 
Mouton, 1996:103-109). A phenomenological method using narratives (Holloway \& Wheeler, 1996:59) was applied to obtain data that would facilitate comprehension of what professional nurses understand under the term 'clinical supervision'. Themes were identified and recommendations made to assist professional nurses in their role as supervisors.

\section{Population}

The population consisted of 320 post-basic, second year, Baccalaureate nursing students originating from all over South Africa, who were required to attend a week-long laboratory session in one of six different sentra as part of their Health Services Management practica requirements at a tertiary educational institution. All these students are professional nurses.

\section{Sampling}

A convenience sample, consisting of a group of 19 Baccalaureate nursing students (professional nurses) who attended one, of two possible practica laboratory sessions in Durban, was selected from second year students.

\section{Data collection}

The data collection process was unstructured and was done by means of narratives also referred to as naive sketches (Giorgi, 1985:10-19). Gadow (1996:8) considers any description of a situation as a narrative. Polkinghorne (in Hatch \& Wisniewski, 1995:5-6) is of the opinion that human activities are described in narratives as goal-directed interaction in the world within which they live. Narratives thus refer to a specific type of discourse which is appropriate for expressing human experience.

The participants were gathered at one of the tertiary institution's regional offices for a skills development session as part of their Health Services Management course. They were asked to use a blank sheet of paper and were required to describe "What do you consider clinical supervision to be?", without any guidelines being given.

\section{Ethical considerations}

The ethical measures adhered to during the research process are those set out by DENOSA (Democratic Nurses Association of South Africa, 1998:3-7) and included informed consent, confidentiality and anonymity, and protection from psychological harm.

At the end of the week-long session, the students were given a choice to participate or not, and were ensured that anonymity and confidentiality would be maintained as they were not required to identify themselves on their narrative sketches.

\section{Trustworthiness}

Trustworthiness refers to ensuring and persuading the reader that the research is worth paying attention to. For a research study to be trustworthy, the four characteristics of credibility, transferability, dependability and confirmability are important to observe (Babbie \& Mouton, 2001:276; Lincoln \& Guba, 1985:290-300).

To ensure credibility, data triangulation was done by using narratives to collect the data. A literature review was undertaken to clarify the different concepts and two independent coders scanned and interpreted the data.

Confirmability was achieved by making use of an independent coder to identify relationships, central themes and categories to confirm that the interpretations were valid.

A literature control was used to compare the findings with established concepts and consensus discussions between the researcher and independent coder were held to ensure dependability.

\section{Data analysis}

Data from the narrative sketches were prepared for importing into a qualitative data analysis program, through which data management was done. The computer software used for coding the data was the QSR NUD*IST 4.0 program. This technique of data analysis is supported by Giorgi (1985:20-30) and Kerlinger's (1986:42-46) guidelines which contain the following steps that were followed in the data analysis process: 
- $\quad$ Reading through the narrative sketches in order to be informed about the content before importing the data into the computer.

- $\quad$ Identifying words and themes.

- $\quad$ Creating nodes for classification purposes.

- Classifying words and themes into major categories.

Clustering words and themes into subcategories.

An independent coder, who is adept in management functions, was used as a credibility measure in making sure that the identified themes and categories were congruent with the data.

\section{RESULTS AND DISCUSSION}

Three major themes were identified from the data, namely patient care, effective teaching and management related aspects. The themes and categories that were identified through analysis of the written narratives confirmed that clinical supervision was not an unfamiliar concept to the respondents. The coding system and data categories are presented in Table 1. It is however clear that in practice, the process of reflection does not consciously occur during the supervisory process as not a single respondent in- dicated reflection as a relevant component of clinical supervision.

\section{Patient care}

Professional nurses identified two categories from their experiences and perceptions regarding clinical supervision that were relevant to patient care, namely that of holistic and quality patient care. These categories are very close as holistic care forms part of rendering quality patient care.

\section{Holistic patient care}

Holistic patient care refers to care which takes cognisance of the client's mind, body and soul. Watson (1985, in Traynor, 1999:69) sees the goal of caring as to help those cared for to a higher level of harmony in mind, body and soul. Nursing care should thus not be focused only on physical disorders. Some of the participants indicated that clinical supervision should serve as a means to ensure that holistic patient care takes place as evidenced by "...clinical supervision is the supervision of how health is promoted with regards to patients, it is whereby effective patient care is given holistically ...".

\section{Table 1: Distribution of main themes and categories}

\begin{tabular}{|c|c|}
\hline MAIN THEME & CATEGORY \\
\hline Patient care & $\begin{array}{ll}\text { - } & \text { Ensures holistic patient care } \\
\text { - } & \text { Provides quality patient care }\end{array}$ \\
\hline Teaching & $\begin{array}{ll}- & \text { Enables hands on teaching } \\
- & \text { Allows effective teaching } \\
\text { - } & \text { Encourages correlation of theory and } \\
& \text { practice } \\
\text { - } & \text { Provides guidance and correction }\end{array}$ \\
\hline Management & $\begin{array}{ll}- & \text { Enables goal achievement } \\
\text { - } & \text { Facilitates change } \\
\text { - } & \text { Implements standards and guidelines } \\
\text { - } & \text { Facilitates control } \\
\text { - } & \text { Assists with managerial tasks }\end{array}$ \\
\hline
\end{tabular}




\section{Quality patient care}

The participants stressed that clinical supervision supports the quality of patient care. Quality assurance in patient care has been defined as an estimation of the degree of excellence in patient health outcomes as well as in activity and other resource outcomes (Swansburg, 1993:384). Kohner's (1994:2) definition of clinical supervision postulates that clinical supervision is a formal arrangement enabling nurses to discuss their work regularly with another experienced professional. It involves reflecting on practice in order to learn from experience and improve competence. This reflects the main aims of clinical supervision, which not only benefits the person being supervised but in doing so, offer a mechanism for improving the quality of patient care by

- maintaining and safeguarding standards of care

- valuing the development of professional and practice knowledge

- ensuring the optimal delivery of quality care (Driscoll, 2000:51).

The participants substantiated their quest for quality patient care facilitated by clinical supervision by means of the following statements: "...is whereby the supervisor exercises her leadership role doing overall supervision of her staff to improve the quality of health care...", "... supervision improves on the quality of care being given...", "... supervision of subordinates and colleagues when doing procedures for the purpose of diagnosis and treatment, and resulting in the quality of life for the patients...".

\section{Teaching}

Because supervisors represent the interface between the planned curriculum and the instruction experienced by students, their influence on the quality of education continues to be immense. Supervisors making action decisions on a day-to-day basis will define quality education, and their decisions will shape a new instructional age in the decades to come. The supervisor is considered the linchpin in the leadership team and the key player in improving learning opportunities for students (Wiles \& Bondi, 2000:v).

The respondents identified four categories relevant to teaching, namely hands-on teaching, effective teaching, correlation of theory and practice, and guidance and correction.

\section{Hands on teaching}

It is a known fact that learning takes place more successfully when more than one sense-organ is involved in the learning process. In addition, personal experience and exercise enhance successful outcomes during the learning phase and ensures internalisation of the content and skills. In the clinical field, students, subordinates and colleagues are continuously performing nursing related tasks. It is thus an advantage to have a clinical expert in the form of a clinical teacher or supervisor at hand (Stengelhofen, 1993:4) to assist as a task is being performed and where guidance is sought.

Some participants indicated that clinical supervision provided them with the opportunity to learn and be supervised while doing their daily tasks, they thus experienced clinical supervision as "...hands-on supervision in a unit..." and it "... can be done on the spot or as arranged ....".

\section{Effective teaching}

When a supportive relationship is set up between the learner/colleague and the supervisor, in which the learner is assisted towards becoming a self-motivated, self-directed learner, then the ground is ready for the provision of opportunities which will promote the student's learning. Good, well-targeted teaching procedures should be used to ensure that the student's time is productive, and that valuable staff resources are used efficiently and effectively (Stengelhofen,1993:5).

Participants indicated that clinical supervision supported effective teaching in the following ways: "...is the process of following up what you have been teaching ...", "... to ensure effective teaching has occurred or not ..." and "... the supervisor can identify the areas that need to be improved and arrange for in-service training ..." .

\section{Correlation of theory and practice}

Nurse training relies heavily on both theoretical class teaching and clinical application of the new knowledge, thus the integration of theory and practice is essential in ensuring successful learning outcomes. The participants emphasised the value of clinical supervision in the correlation of theory and practice as is substantiated by the following statements: "... teaching in a real clinical environment ...", "...practical 
part of nursing where the reality of nursing is ...", "... is a set standard of teaching where theory is put into practice..." and "...mostly students memorise the facts or concepts from the theory then the facilitator will clarify those concepts relating them to the practice position of the work ..." .

\section{Guidance and correction}

According to Orem (1995:16-17) guiding another person is considered a method of assisting, and is valid in situations in which a person needs to make choices, for example, choosing one course of action in preference to another, or to pursue a course of action, but not without direction or supervision. This requires that the person extending guidance and the person being guided must be in communication with one another. In turn, the guidance given must be appropriate, whether in the form of suggestions, instructions, direction or supervision. The concept of guiding another is often used in conjunction with supporting one another.

Most participants clearly indicated that a major function of clinical supervision was encompassed in the accompaniment, guidance and correctional role of the supervisor. The experienced practitioner thus has a firm responsibility in being there for his/her subordinates and colleagues, so that they may be observed, assisted, guided, led, checked and corrected where necessary. This view is substantiated by statements as these: “... is coping or helping learners ...", "... observations and corrections ...", "...lead and direct ...", "...assisting, leading, guiding one through nursing practices ...", "... is the guidance ...continuous assessment and evaluation of students and personnel ... to ensure the highest standards of nursing care are adhered to.... and rendering of efficient patient care ..." and "...guidance by an experienced senior and qualified staff member ... to acquire skills, efficiency as well as uniformity within accepted norms ..." .

\section{Aspects related to management}

The respondents identified five categories under management related aspects. And even though they indicated that supervisors (as managers) had certain obligations towards them being supervised such as providing guidelines for proposed activities, the clinical supervisory process could also be applied to the ben- efit of management. The categories identified were goal achievement, facilitation of change, control, standards and guidelines, and various management tasks.

\section{Goal achievement}

The basic tools of management planning are statements of mission, philosophy, goals and objectives, and an active operational or management plan (Swansburg, 1993:68). Objectives must be converted into actions such as activities, assignments, and deadlines all with clear accountability. Participants indicated in the following manner that clinical supervision was beneficial to goal achievement: "... aims and goals are to be obtained ..." and "...it is the supervision of personnel constructively in order to achieve the goals of the unit...".

\section{Facilitation of change}

As a catalyst, the nurse manager causes or accelerates change by using knowledge and skills that are not permanently affected by the reaction. In essence, the nurse manager may be considered a change agent (Swansburg, 1993:196). In being a change agent the manager is well-suited in her supervisory role to share and acquire information related to the proposed change. Participants indicated that change may be enhanced by clinical supervision, this is verified by the following quotations: "... is assisting with positive changes in the unit ..." and "... it gives managers information that will be used ...for promoting change in a positive way ...".

\section{Standards and guidelines}

Policies, procedures, rules and regulations are the standing plans of the nursing organisation. Standing plans are fixed in both nature and content, they apply until reviewed and modified or are abandoned. Policies need to include standards applicable to the practising nurse, particularly with regard to clinical privileges and standards of professional ethical practices (Swansburg, 1993:169). Policies, standards and guidelines therefore provide direction for professional conduct and behaviour. Participants were of the opinion that through clinical supervision, standards and guidelines are conveyed and implemented: "...standards are formulated and should be understood by everybody...”, "...are given guidelines by providing them with protocols, standing orders as to know what is done ..." and "...clinical guidelines, protocols and indicators serve as basis for clinical heal- 
ing care delivery ...".

\section{Control}

Control is a process which ensures that pre-determined standards are attained and maintained, policies are adhered to as far as is humanely possible, and preventative measures are employed where deviation from predetermined goals is a threat to safe patient care. According to Jooste (in Booyens, 1996:293) the control process ensures that signs of possible deviation from set standards and norms are detected in time and that reliable information is obtained upon which future planning can be based. The participants indicated by means of their narrative sketches that clinical supervision was indeed a means of controlling the activities of colleagues, as is evident from the following quotations: "...to check whether work given has been done or not ...", "... to make sure things are done as guided by the act of nursing ...", "... control and evaluation ...", "... activities are checked to make sure everything is done properly and correctly ..." and "... gives the supervisor opportunity to look at availability of equipment or resources ...utilised effectively ...in good working condition ...".

\section{Managerial tasks}

Management is the process of influencing others with the specific intention of getting them to perform effectively and contribute to meeting the organisation's goals (Drucker, 1967:3). A manager is formally and officially responsible for the work of a given group, for ensuring that the necessary amount of work is done, and that it is done well. To fulfil this responsibility, the manager may be expected to hire and fire people. Formally evaluate staff members, recommend raises and promotions, prepare and implement the budget, approve expenses and purchases, review the work done by staff members, handle conflicts, contribute technically, and plan the current and future activities of the department (Tappen, 2001:6). Participants supported the view that clinical supervision enabled management to fulfil its managerial role by overseeing "... the processes of planning, organising, directing or leading and controlling ..." and "... is the management of nursing care and workers by the manager through assessment, diagnosis, planning, preimplementation, implementation, recording and evaluation...".

\section{CONCLUSIONS}

It is evident from the professional nurses' responses that they were familiar with the meaning of the concept 'supervision', the reasons for, and some of the content of the clinical supervisory role. They did however not see it as an empowering process. The following concluding statements are made:

- Patient care is assisted and improved by clinical supervision, as holistic, quality care rendering is promoted.

- Teaching (and learning) is enhanced as clinical supervision is a hands-on involvement, aims at effective teaching, serves as a means for correlating theory and practice, and supports colleagues through guidance, correction and accompaniment.

- Management benefits by clinical supervision as goal achievement is advanced, change is facilitated, standards and guidelines are conveyed and implemented, serves as a control measure to ensure that policy and standards are adhered to, and enables a variety of managerial functions.

- One deficiency that is evident from the conclusions is that the value of reflective thinking was not considered part of clinical supervision, while it was accounted an important component of effective supervision by several authors. This raises a concern for selfawareness of one's own clinical practice standards and the transformation of clinical practice.

\section{Limitation}

As reflection is such a critical part of effective supervision, the research question could have been formulated to include this concept.

\section{RECOMMENDATIONS}

On the basis of the professional nurse's knowledge of, and about, clinical supervision as indicated in the conclusions, brief guidelines will now be given, based on the Cyclical Model of Page and Wosket (in Van Ooijen, 2000:11) as to how the supervisory process can be enhanced. 


\section{Guidelines for enhancing clinical super- vision}

1. Establish a contract by

- $\quad$ setting the ground rules for behaviour within the supervisory process (for example meeting times)

- determining the limits and boundaries within which all parties should function (for example confidentiality and preferred processes)

- allocating accountability and responsibility for tasks and functions (for exampe long-term plans and deadlines)

- acknowledging the expectations of all parties concerned (for example needs and agreements)

- confirming the relationships that will be derived from the process (for example mentorship or supporters)

2. Identify a focus by

- ascertaining what the focus (topic/issue) of the supervisory process will be

- clarifying objectives in order for both parties to know the purpose of bringing a topic/issue to supervision

- determining the format in which the topic should be presented (if applicable, for example verbal presentation or portfolio)

- establishing the approach that will be followed (for example role modelling or person-centred)

- setting priorities if the tasks and functions are varied in nature and importance.

3. Creating space by

- being tolerant of uncertainty, confusion and lack of knowledge and skill

- encouraging collaboration and support through an alliance of reflective practice

- fostering a sense of investigation to meet challenges and solve problems

- accommodating personal and professional development and growth

- affirming successes and progress and permitting mistakes as part of the growth process.

4. Build a bridge by

- consolidating a clearer perspective after thor- ough reflection on a matter

- providing relevant information, knowledge or experience if it is appropriate

- assisting the supervisee to set goals and plan action while considering the client's well being and perspective.

5. Review by

- receiving and providing feedback on demonstrated behaviour and competence

- assessing the supervisory process in terms of what worked and what was not successful

- building in regular reviews of the whole process as a measure of striving for excellence.

\section{CONCLUDING REMARKS}

The quality of patient care is often criticised and lamented which questions the effectiveness of the supervisory function of experienced and qualified professional nurses. The focus of this research was to explore and describe the views of professional nurses with regard to what they considered clinical supervision to be.

The results which are substantiated by literature were grouped into three themes, each with several categories. The participants indicated their understanding of clinical supervision which is congruent with the literature, but refrained from indicating that supervision is a process within which reflection plays an important role. Brief guidelines were provided to assist practitioners in the process of enhancing clinical supervision.

\section{Acknowledgements}

The professional nurses involved in this study are hereby thanked for their inputs and time amidst the pressure of being distance education students.

\section{REFERENCES}

BABBIE F \& MOUTON J 2001: The practice of social research. Cape Town: Oxford University Press.

BANDMAN, EL \& BANDMAN, B 1995: Critical thinking in nursing; $2^{\text {nd }}$ edition. Norwalk: Appleton \& Lange.

BISHOP, V ed. 1998: Clinical supervision in practice - some ques- 
tions, answers and guidelines. London: Macmillan.

BOOYENS, SW ed. 1996: Introduction to health services management. Kenwyn: Juta

BROOKFIELD, S 1987: Developing critical thinkers: challenging adults to explore alternative ways of and acting. Milton Keynes: Open University Press.

BURNS, S \& BULMAN, C 2000: Reflective practice in nursing. London: Blackwell Science.

BUTTERWORTH, T 1998: Clinical supervision as an emerging idea in nursing. (In: Butterworth, T \& Faugier, J eds. 1998: Clinical supervision and mentorship in nursing; $2^{\text {nd }}$ edition. Cheltenham: Stanley Thornes).

BUTTERWORTH, T \& FAUGIER, J eds. 1998: Clinical supervision and mentorship in nursing; $2^{\text {nd }}$ edition. Cheltenham: Stanley Thornes. DENOSA 1998: Ethical standards for nurse researchers. DENOSA'S position statements. Pretoria: DENOSA.

DEPARTMENT OF HEALTH 1998: A first class service - Quality in the new NHS. London: Department of Health.

DRISCOLL, J 2000: Practicing clinical supervision, a reflective approach. Edinburgh: Bailliere Tindall.

DRUCKER, PF 1967: The effective executive. New York: Harper \& Row.

GADOW, S 1996: Ethical narratives in practice. Nursing Science Quarterly, 9(1):8-9.

GIORGI, A ed. 1985: Phenomenology and psychological research. Pittsburg: Duquesne University Press.

HATCH, JA \& WISNIEWSKI, R ed. 1995: Life history and narrative. London: Falmer.

HOLLOWAY, I \& WHEELER, S 1996: Qualitative research for nurses. London: Blackwell Science.

KERLINGER, FN 1986: Foundations of behavioural research. Chicago: Holt, Rinehard \& Winston.

KOHNER, N 1994: Clinical supervision in practice. London: King's Fund Centre.

LINCOLN, YS \& GUBA, EG 1985: Naturalistic inquiry. California: Sage.

MEYER, L 2001: Lyk dalk opgegrawe nà voorval in hospitaal. ("The possibility of digging up a corpse after an incident in hospital').

Rapport, 2 December 2001:10.

MOUTON, J 1996: Understanding social research. Pretoria: Van Schaik.

MOUTON, J \& MARAIS, HC 1992: Basiese begrippe: Metodologie van Geesteswetenskappe. Pretoria: Raad vir Geesteswetenskaplike Navorsing.

NASH, E 1990: Supervisory training: teaching people skills. HRM 1990 Yearbook, 1990:72-73.

OREM, DE 1995: Nursing concepts of practice; $5^{\text {th }}$ edition. Chicago: Mosby.

PAUNONEN, M 1991: Promoting nursing quality through supervi- sion. Journal of Nursing Staff Development, September/October 1991:229-233.

SEVERINSSON, EI \& HALLBERG, IR 1996: Clinical supervisors' view of their leadership role in the clinical supervision process within nursing care. Journal of Advanced Nursing, 24:151-161.

STENGELHOFEN, J 1993: Teaching students in clinical settings. London: Chapman \& Hall.

SWANSBURG, RC 1993: Introductory management and leadership for clinical nurses. Boston: Jones \& Bartlett.

TAPPEN, RM 2001: Nursing leadership and management concepts and practices; $4^{\text {th }}$ edition. Philadelphia: FA Davis.

TAYLOR, B 1994: Being human - ordinariness in nursing. Edinburgh: Churchill Livingstone.

TAYLOR, BJ 2000: Reflective practice. Buckingham: Open University Press.

TRAYNOR, M 1999: Managerialism and nursing beyond oppression and profession. New York: Routledge.

VAN ASWEGEN, EJ; BRINK, HIL \& STEYN, PJN 2000: A model for facilitation of critical reflective practice. Curationis, 23(4):123127.

VAN OOIJEN, E 2000: Clinical supervision a practical guide. Edinburgh: Churchill Livingstone.

VAN WYK, A 2001: Verskriklik om jou ma sò in tehuis te sien'. ( 'It's terrible to see your mother like this in an old age home'). Rapport, 2 December 2001:10.

WILES, J \& BONDI, J 2000: Supervision a guide to practice; $5^{\text {th }}$ edition. Columbus, Ohio: Merrill of Prentice Hall. 